Click www.researchjournal.co.in/online/subdetail.html to purchase.

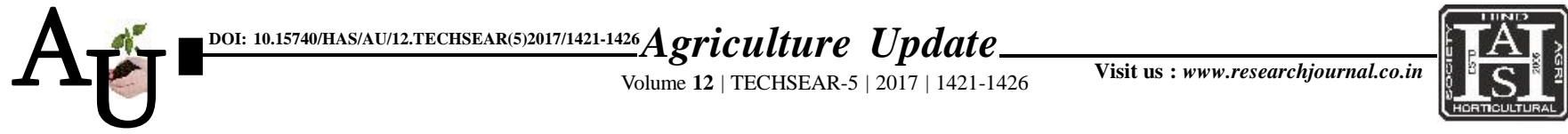

\title{
Rевевсн автіске: Study of soil physical and Microbialproperties of soil as influenced by weed management in maize (Zea mays L.)
}

\author{
PRADEEP KUMAR DEWANGAN, P. MAHAPATRA, SOORAJ CHANDRA \\ PANKAJ, PRATIMA KUMARI, LOMENDRA KUMAR KULHARY AND \\ VARUN KUMAR
}

Article Chronicle: Received :

15.07.2017;

Accepted :

30.07.2017

KeY Words :

Dehydrogenase,

Maize, Microbial

population, Physical

properties

Author for correspondence : PRADEEP KUMAR

DEWANGAN

Department of

Agronomy, Ranchi

Agriculture College,

Birsa Agricultural

University, Kanke,

RANCHI (JHARKHAND)

INDIA

Email : dewangan2050@

gmail.com

See end of the article for

authors' affiliations
SUMMARY : A field investigation was conducted at BAU experimental Farm, Ranchi during Kharif season 2015 on sandy clay loam soil. The experiment was laid out in a RBD with 13 treatments: atrazine $0.5+$ pendimethalin $0.5 \mathrm{~kg} / \mathrm{ha} \mathrm{PE}$, two hand weeding at 20 and $40 \mathrm{DAS}$, two mechanical weeding at 20 and $40 \mathrm{DAS}$, atrazine $1.0 \mathrm{~kg} / \mathrm{ha} \mathrm{PE}$, pretilachlor $0.5+$ metribuzin $0.175 \mathrm{~kg} / \mathrm{ha} \mathrm{PE}$, metribuzin $0.35 \mathrm{~kg} / \mathrm{ha}$ at $15 \mathrm{DAS}$, pendimethalin $1.0 \mathrm{~kg} / \mathrm{ha} \mathrm{PE}$, atrazine $1.0 \mathrm{~kg} / \mathrm{ha}$ at $15 \mathrm{DAS}$, metribuzin $0.35 \mathrm{~kg} / \mathrm{ha} \mathrm{PE}$, pretilachlor $1.0 \mathrm{~kg} / \mathrm{ha}$ PE, pretilachlor $1.0 \mathrm{~kg} / \mathrm{ha}$ at $15 \mathrm{DAS}$, green manuring by Sesbania @ $80 \mathrm{~kg} / \mathrm{ha}$ fb 2, 4-D 0.625 $\mathrm{kg} / \mathrm{ha}$ at 30 DAS and weedy Check, replicated thrice.. Maize var.Suwan was sown (on 30-06-2015) with spacing of $70 \times 20 \mathrm{~cm}$, seed rate $20 \mathrm{~kg} / \mathrm{ha}$ and RDF 120:60:40 kg/ha. Result revealed that soil physical propertiessuch as $\mathrm{pH}$, organic carbon and EC observed non-significantly affected with different weed management practices but $\mathrm{CO}_{2}$ was observed maximum with green manuring by Sesbania @ $80 \mathrm{~kg} / \mathrm{ha}$ $f b 2,4-\mathrm{D} 0.625 \mathrm{~kg} / \mathrm{ha}$ at 30 DAS.Population of soil microbial biomass (fungi, bacteria and Actinomycetes) was at par with all the different weed management practices. Dehydrogenase activity ( $\mu \mathrm{g}$ TPF $\mathrm{g}^{-1}$ soil day $^{-1}$ ) and azotobacter count observed significantly highest with the application of green manuring by Sesbania @ $80 \mathrm{~kg} / \mathrm{ha} f b 2,4-\mathrm{D} 0.625 \mathrm{~kg} / \mathrm{ha}$ at $30 \mathrm{DAS}\left(\mathrm{T}_{10}\right)$.

How to cite this article : Dewangan, Pradeep Kumar, Mahapatra, P., Pankaj, Sooraj Chandra, Kumari, Pratima, Kulhary, Lomendra Kumar and Kumar, Varun (2017). Study of soil physical and Microbialproperties of soil as influenced by weed management in maize (Zea mays L.). Agric. Update, 12(TECHSEAR-5) : 1421-1426; DOI: 10.15740/HAS/AU/12.TECHSEAR(5)2017/1421-1426. 